\title{
Scope of Improvement in Soil Fertility Build-up with Khejri Based Crop Production Systems under Hot Arid Agro-Climate
}

\author{
Dinesh Kumar*, D.K. Samadia, M.K. Jatav, S.R. Meena, B.D. Sharma and D. Singh \\ ICAR-Central Institute for Arid Horticulture, Beechwal, Bikaner - 334006 (Rajasthan), India \\ *Corresponding author
}

\section{A B S T R A C T}

\section{Keywords \\ Khejri based cropping models, Soil fertility, Nutrients, Scope of improvement, Hot arid environment, Cluster bean and Vegetables. \\ Article Info \\ Accepted: 17 June 2017 Available Online: 10 July 2017}

A long-term investigation to under-stand soil fertility and scope of improvement in building-up of fertility and nutrient levels was carried-out adopting khejri based crop production site management approaches at ICAR-Central Institute for Arid Horticulture, Bikaner under hot arid agro-climate. A wide spectrum of varying land-use patterns (47 situation) were studied with or without khejri planting models $\left(3,6\right.$ and $9^{\text {th }}$ years group) and for this virgin sand-dune landscape field was developed and studied for nutrient buildup and soil fertility characters over the period from 2004-2015 as innovative production site approach. The analyzed data of varying 47 situations under investigation depicted wide range for soil $\mathrm{pH}(8.27-8.92)$, TDS (37 -130 ppm), EC (0.057 -0.203 ds/m), OC (0.068-0.100\%), N (72.73-107.76 kg/ha), P (8.11- $11.56 \mathrm{~kg} / \mathrm{ha}), \mathrm{K}(181.84-246.00 \mathrm{~kg} / \mathrm{ha})$ and $\mathrm{S}(3.50-8.27 \mathrm{~kg} / \mathrm{ha})$ and results exhibited that the approach is effective in improving the organic carbon and nutrient status in sandy soils. The treatment code KS-39 (KM-11, field of khejri plantation of nine years age-group with cluster bean cultivation) exhibited more effectiveness for soil fertility build-up in comparison to different land-use patterns. Based on 6 year age-group, treatment code KS-13 (KM-1, field of 4mx4m khejri plantation with three cluster bean crops during establishment period and normal field crop culture as organic plot) is found more effective for soil fertility build-up in comparison to other land-use patterns of the period. Among khejri models of three years age-group, treatment code KS-12 (KM-9, field of $24 \mathrm{mx} 4 \mathrm{mx} 4 \mathrm{~m}$ plantation of 3 years of establishment with three rainfed cluster bean crop) depicted effectiveness for better soil fertility build-up. The analyzed data evidently demonstrated that virgin sand-dune land-scape developed as fields for crop cultivation under hot arid agro-climate can effectively be improved with khejri plantations and three crops of cluster bean for building-up of nutrients status, and it should be developed as systematic khejri based production sites for cultivation of diverse and resource based crop-commodities.

\section{Introduction}

The International Treaty on Plant Genetic Resources for Food and Agriculture (ITPGRFA) has identified 64 priority crops or crop complexes for conservation and sustainable use, and out of them Prosopis is under forage-legume, and it has diversified potentialities of exploitation. Khejri (Prosopis cineraria) has long been exploited as a nutritive fodder for animals and multi-purpose tree for mankind in dry-lands of Indian Thar Desert. But it's potential as high nutritive value vegetable crop-plant and drought tolerance in a world facing global warming underscore its growing importance for 
sustainable agriculture and eco-restoration. Native crop-plants both annual and perennial are playing an equally vital role for food and fodder especially in desert eco-system of Rajasthan where animal husbandry is an integral part of agriculture and which receives only $150-350 \mathrm{~mm}$ rains in 1-5 erratic spells during the monsoon. With changed scenario and climatic variations, now, it is necessity to have new concepts with most prospective native species i.e. khejri for breaking yield gaps and sustainability through agri-hortisilvi-pastoral mode, and adopting horticulture based crop production site management approach (HBCPSMA -Samadia, 2004).

Khejri (Prosopis cineraria) is a leguminous tree species of hot arid and semi-arid region of north-western parts of India. It not only tolerates the extreme edapho-climatic conditions of the regions with lush green foliage but also bears flowers and fruits and that too during the driest period. It is a multipurpose tree for nutritious rich pods, valuable fodder and fuel, besides its favourable impact on ecology and soil fertility (Dwivedi et al., 1999; Samadia et al., 2002 and Purohit et al., 2003). It is an important perennial component compatible to almost any companion crop in agri-horti-forestry systems of production (Pareek and Purohit, 2002 and Samadia et al., 2006). The technological advancement in khejri (bud grafting as vegetative method of propagation and variety Thar Shobha) at CIAH, Bikaner resulted into wide spreading popularization of this versatile and life-line tree of Indian desert. The newer recommended technologies are in faster way of adoption for establishing uniform plantations for tender pods / sangri production and also cropping systems with diversified crop-commodities under resource constraint environment (Pareek et al., 2003; Pareek et al., 2006 and Samadia, 2014).

Rajasthan state is a marginal zone for agricultural production and the extremes of high and low temperature and scanty rainfall together with associated abiotic stressed conditions limiting the crop choice and productivity levels. The long-established farming systems have provided sustenance to the desert dwellers and thus, the predominantly mixed cropping needs multidimensional interventions through native crop-plants and newer technological advancements, and it is now potentially be exploited with the concept - Khejri based crop production site management approach and it can be an innovative tool for enhancing yield, improving soil fertility and doubling farm income. The approach is much helpful in creating favourable micro-climate in production sites and minimizing ill-effects of environmental adversity. This approach would ultimately results into optimal use of land, water and vegetation in an integrated way for eco-restoration and social prosperity. Therefore, long-term strategic studies were initiated with 12 planting models under varying situations and objectives to develop khejri based crop production models and to understand impact of cropping system both under rainfed and irrigated situations (Samadia, 2015), and the present paper is to understand scope of improvement in soil fertility build-up and nutrient status with varying land-use patterns.

\section{Materials and Methods}

The sand-dune and desertic land-scape study area of ICAR-CIAH research farm is situated in village Beechwal $\left(28^{0} 6^{\prime} \mathrm{N}\right.$ latitude and $73^{0} 2^{\prime}$ E longitude and altitude 223 masl) at 10 $\mathrm{km}$ north-west of Bikaner city. The critical analysis over 15 years of study site depicted that experimental farm site is under extremely arid zone and March-October months experiences as hot, dry, shiny and continuous high temperature around $38^{\circ} \mathrm{C}$ for prolonged period, and resulted to excessive evapotranspiration. The maximum temperature in May-June varies from $40-42^{0} \mathrm{C}$ but it is very 
common to have high temperature range from $48-50^{\circ} \mathrm{C}$ for number of days. The winter is dry and minimum temperature is ranged from 4-10 $\mathrm{C}$ in December-January and sometimes it prolonged up to February. Most of the years, minimum temperature dips-down below freezing point $\left(-1\right.$ to $\left.-6^{0} \mathrm{C}\right)$ and occurrence of frost is frequent in farm production site of the hot arid land.

The sand-dune farm land was developed during 2002-04 and sandy field soil was coarse texture and poor in water retention capacity. For the long-term studies, nine hectare area was utilized as khejri based production site adopting in-situ orchard establishment techniques with varying landuse pattern and planting models. Khejri as base crop with varying planting models such as KM-1 $(4 \times 4 \mathrm{~m}), \mathrm{KM}-2 \quad(6 \times 6 \mathrm{~m}), \mathrm{KM}-3$ (8x8m), KM-4 (8x4m), KM-5 (8x4x4m), KM-6 (16x4m), KM-7 (16x4x4m), KM-8 (24x4m), KM-9 (24x4x4m), KM-10 (48x4m), KM-11 (48x4x4m) and KM-12 (scattered / natural plants) is long-term, strategic and innovative research under HBCPSMA concept for promotion of horticulture in drylands. For the preset investigation, wide spectrum of varying land-use patterns (47 situations given in table 1) were studied with or without khejri planting models $\left(3,6\right.$ and $9^{\text {th }}$ years age group) to understand nutrient buildup, soil fertility characters and scope of improvement over the period from 2004-2015 as production site approach. The soil samples and data were analyzed adopting standard procedures to understand the results of new initiatives and follow up of action for further refinements.

\section{Results and Discussion}

The primary objective of soil conservation is to maintain and improve soil fertility status for effective crop culture. For this, maintenance of physical properties, addition of organic matter, improvement in nutrient status and control of erosion is necessary for defined land-scape. In this context, the present study was undertaken as long-term research innovation for soil fertility build-up adopting khejri based cropping system with variable land-use pattern for agri-hortipastoral production under hot arid environment of desert eco-system. Comparative data from different pattern of land-use (Table 2) giving a clear picture for soil fertility status and build-up under variable 47 situations with or without khejri based production system. The status of nitrogen, phosphorus, potassium, sulphur and other soil properties enhanced and recorded as increase with $9^{\text {th }}$ year age-old khejri plantation in comparison to plots without trees and $3^{\text {rd }}$ and $6^{\text {th }}$ year age-old plantation sites of khejri. The results have ample evidences and demonstrated that soil surface with khejri trees were richer in organic matter and nutrients then soil surface area without trees, and thus signifies the importance of khejri plantation on the sand-dunes and desertic land-scape.

The analyzed soil data for 47 variable plot situations mentioned in table 2 indicated comparable wide range for $\mathrm{pH}$ (8.27-8.92), TDS (37-130 ppm), EC (0.057-0.203 $\left.\mathrm{dSm}^{-1}\right)$, OC (0.068-0.100\%), N (72.73-107.76 kg/ha), P (8.11-11.56 kg/ha), K (181.84- 246.00 $\mathrm{kg} / \mathrm{ha})$ and $\mathrm{S}(3.50-8.27 \mathrm{~kg} / \mathrm{ha})$ status. The mean values from the 47 samples of soil is for pH-8.65, TDS-67, EC-0.105, OC-0.088 \%, N$94.32 \mathrm{~kg} / \mathrm{ha}, \mathrm{P}-9.92 \mathrm{~kg} / \mathrm{ha}, \mathrm{K}-217.75 \mathrm{~kg} / \mathrm{ha}$ and $\mathrm{S}-6.14 \mathrm{~kg} / \mathrm{ha}$, and the data verified that there is enough scope in improving the requisite nutrients and fertility status in the sandy soils with systematic planting of native crop-plants and cluster bean cultivation.

A perusal of data in table 2 revealed that treatment code KS-39 soil sample $\mathrm{pH}$, TDS and EC were 8.27, $37 \mathrm{ppm}$ and $0.058 \mathrm{dSm}^{-1}$ 
which is $4.39,44.77$ and $44.97 \%$ lesser than mean values of $\mathrm{pH}$, TDS and EC, respectively. From data, it is evident that maximum organic carbon content is recorded with KS-39 i.e. 0.100 which is $14.28 \%$ higher than mean from total sample values and higher organic carbon content is good indication for soil physical properties as well for crops under cultivation.

The available N, P, K and S are highest with treatment code KS-39 and it is 107.76, 11.56, 246 and $8.27 \mathrm{~kg} / \mathrm{ha}$ and is $14.24,16.56,12.97$ and $34.69 \%$ higher from average values of $\mathrm{N}$, $\mathrm{P}, \mathrm{K}$ and $\mathrm{S}$ as treatments under investigation, respectively. These findings clearly demonstrated that khejri planting model KM11 (paired rows at $48 \mathrm{mx} 4 \mathrm{~ms} 4 \mathrm{~m}$ ), a wide spacing paired rows of budded khejri and regular cluster bean cultivation is much efficient in improving soil fertility and building-up nutrient status in desertic sandy soils, and this model is suitable for diverse crop cultivation and also better for mechanization with larger size fields.

The $\mathrm{pH}$, TDS and EC of treatment KS-39 are $1.45 \%, 10.81 \%$, and $10.34 \%$ lesser than the best treatment of virgin sand-dune land (KS5 ), respectively. The organic carbon of this treatment is increased by $3 \%$ than the value of OC of KS-5 as virgin sandy land.

There is distinguished increase in value of $\mathrm{N}$ (7.0 \%), $\mathrm{P}(4.41 \%), \mathrm{K}(19.72 \%)$ and $\mathrm{S}$ $(8.82 \%)$ content in comparison to KS-5 soils. When we compare the KS- 39 with the best treatment of three years of establishment and cultivated land i.e. KS-12 (KM-9, paired rows at $24 \mathrm{mx} 4 \mathrm{mx} 4 \mathrm{~m}$ ), it is observed that $\mathrm{pH}$, TDS and $\mathrm{EC}$ of $\mathrm{KS}-39$ is $1.21 \%, 10.81 \%$ and $10.34 \%$ lesser than KS-12, respectively. The organic carbon of KS-39 is one per cent higher than KS-12, and this results depicted scope for continual improvement in soil fertility through khejri plantations and cluster bean cultivation. This increased $\mathrm{N}, \mathrm{P}, \mathrm{K}$ and $\mathrm{S}$ content is by $2.78 \%, 3.55 \%, 7.51 \%$ and $7.86 \%$ respectively.

When comparison is made with six years of cultivated field soil i. e. KS-13, pH of KS-39 is $0.61 \%$ lesser than KS-13. There is no much difference for organic carbon between KS-39 and KS-13 (KM-1). With nine years, however, quantity of $\mathrm{N}, \mathrm{P}, \mathrm{K}$ and $\mathrm{S}$ content is enhanced by $1.51,1.90,0.81$ and 3.14 per cent in comparison to six years of cultivated field (KS-13).

The data in table 2 revealed that treatment code KS-13 (model KM-1 plot i.e. $4 \mathrm{mx} 4 \mathrm{~m}$ distance khejri budded plantation of 6 years old with three cluster bean crop during initial establishment phase and normal culture as organic plot) was found much better than that of other experimental plots. The $\mathrm{pH}$, TDS and EC of KS-13 were 8.32, $41 \mathrm{ppm}$ and 0.064 $\mathrm{ds} / \mathrm{m}$ and are 3.81, 38.81 and $39.18 \%$ lesser than mean values of treatments under study. The OC content of experimental field of treatment code KS-13 was $0.1 \%$ and is 14.28 $\%$ higher than average values from experimental sites.

The study indicates that available N, P, K and $\mathrm{S}$ were much better in KS-13 than plots of varying models, and were 106.13, 11.34, 244 and $8.01 \mathrm{~kg} / \mathrm{ha}$, respectively. These essential nutrients were $12.52,14.33,12.05$ and 30.46 $\%$ higher than the average value of these nutrients from experimental plots under investigation for the long-term studies under desert eco-system. Khejri model KM-1 exhibited significance of native crop-plants accommodation on sandy land-scape, and there by building-up of nutrients in soil as well scope for organic crop cultivation after juvenile phase of plantations, and thus this model can be a boon towards minimizing input cost and promotion of sustainable organic farming. 
Table.1 Description of experimental treatment sites from samples studied as khejri based crop fields of sand-dunes soil under hot arid eco-system at CIAH, Bikaner

\begin{tabular}{|c|c|}
\hline Code & Details of experimental plot as treatment description and soil sampled for studies \\
\hline KS-1 & Virgin sand-dune land and as developed fallow field culture under rainfed situations \\
\hline $\mathrm{KS}-2$ & $\begin{array}{l}\text { Virgin sand-dune land and as developed field with three years of bhurhat grass cultivation under } \\
\text { rainfed situations }\end{array}$ \\
\hline KS-3 & $\begin{array}{l}\text { Virgin sand-dunes land and as developed field with three years of dhaman grass cultivation under } \\
\text { rainfed situations }\end{array}$ \\
\hline KS-4 & $\begin{array}{l}\text { Virgin sand-dune land and as developed field with three years of sewan grass cultivation under } \\
\text { rainfed situations }\end{array}$ \\
\hline KS-5 & $\begin{array}{l}\text { Virgin sand-dune land and as developed field with three years of cluster bean cultivation under } \\
\text { rainfed situations }\end{array}$ \\
\hline KS-6 & $\begin{array}{l}\text { Normal sandy soil field with natural and scattered khejri seedlings and prepared and three years } \\
\text { of cluster bean crop cultivation adopting traditional system (Control) }\end{array}$ \\
\hline KS-7 & $\begin{array}{l}\text { Field of khejri }(4 \mathrm{~m} \times 4 \mathrm{~m}) \text { plantation of } 3 \text { years of establishment without cluster bean crop or } \\
\text { fallow field culture }\end{array}$ \\
\hline KS-8 & $\begin{array}{l}\text { Field of khejri plantation ( } 8 \mathrm{~m} \times 8 \mathrm{~m}) \text { of } 3 \text { years of establishment without cluster bean crop or } \\
\text { fallow field culture }\end{array}$ \\
\hline KS-9 & $\begin{array}{l}\text { Field of khejri }(4 \mathrm{~m} \times 4 \mathrm{~m}) \text { plantation of } 3 \text { years of establishment with three season cluster bean as } \\
\text { initial phase crop cultivation }\end{array}$ \\
\hline KS-10 & $\begin{array}{l}\text { Field of khejri }(8 \mathrm{~m} \times 8 \mathrm{~m}) \text { plantation of } 3 \text { years of establishment with three season cluster bean as } \\
\text { initial phase crop cultivation }\end{array}$ \\
\hline KS-11 & $\begin{array}{l}\text { Field of khejri (16mx } 4 \mathrm{~m} \times 4 \mathrm{~m}) \text { plantation of } 3 \text { years of establishment with three season cluster } \\
\text { bean as initial phase crop cultivation }\end{array}$ \\
\hline $\mathrm{KS}-12$ & $\begin{array}{l}\text { Field of khejri ( } 24 \mathrm{mx} 4 \mathrm{~m} \times 4 \mathrm{~m}) \text { plantation of } 3 \text { years of establishment with three season cluster } \\
\text { bean as initial phase crop cultivation }\end{array}$ \\
\hline KS-13 & $\begin{array}{l}\text { Field of khejri }(4 \mathrm{mx} 4 \mathrm{~m}) \text { budded plantation of } 6 \text { years old with three cluster bean crop during } \\
\text { initial phase and traditional crop culture as organic plot }\end{array}$ \\
\hline KS-14 & $\begin{array}{l}\text { Field of khejri budded plantation of } 6 \text { years old }(16 \mathrm{mx} 4 \mathrm{mx} 4 \mathrm{~m})+\text { Three season bhurhat grass } \\
\text { crop. }\end{array}$ \\
\hline KS-15 & $\begin{array}{l}\text { Field of khejri budded plantation of } 6 \text { years old }(16 \mathrm{mx} 4 \mathrm{mx} 4 \mathrm{~m})+\text { Three season dhaman grass } \\
\text { crop. }\end{array}$ \\
\hline KS-16 & Field of khejri budded plantation of 6 years old $(16 \mathrm{mx} 4 \mathrm{mx} 4 \mathrm{~m})+$ Three season sewan grass crop. \\
\hline KS-17 & Field of khejri budded plantation of 6 years old $(6 \mathrm{~m} \times 6 \mathrm{~m})+$ Three cluster bean crop cultivation \\
\hline KS-18 & Field of khejri budded plantation of 6 years old $(8 \mathrm{~m} \times 8 \mathrm{~m})+$ Three cluster bean crop cultivation \\
\hline KS-19 & Field of khejri budded plantation of 6 years old $(8 \mathrm{~m} \mathrm{x} 4 \mathrm{~m})+$ Three cluster bean crop cultivation \\
\hline KS-20 & $\begin{array}{l}\text { Field of khejri budded plantation of } 6 \text { years old ( } 4 \mathrm{mx} 4 \mathrm{~m} \text { paired rows })+ \text { Three cluster bean crop } \\
\text { cultivation }\end{array}$ \\
\hline KS-21 & Field of khejri budded plantation of 6 years old $(16 \mathrm{mx} 4 \mathrm{~m})+$ Three cluster bean crop cultivation \\
\hline KS-22 & $\begin{array}{l}\text { Field of khejri budded plantation of } 6 \text { years old }(16 \mathrm{mx} 4 \mathrm{mx} 4 \mathrm{~m})+\text { Three cluster bean crop } \\
\text { cultivation }\end{array}$ \\
\hline KS-23 & Field of khejri budded plantation of 6 years old $(24 \mathrm{mx} 4 \mathrm{~m})+$ Three cluster bean crop cultivation \\
\hline $\mathrm{KS}-24$ & $\begin{array}{l}\text { Field of khejri budded plantation of } 6 \text { years old }(24 \mathrm{mx} 4 \mathrm{mx} 4 \mathrm{~m})+\text { Three cluster bean crop } \\
\text { cultivation }\end{array}$ \\
\hline $\mathrm{KS}-25$ & $\begin{array}{l}\text { Vegetable field with khejri plantation }(48 \mathrm{mx} 4 \mathrm{~m}) \text { and } 6 \text { years of cluster bean crop cultivation } \\
\text { during rainy season }\end{array}$ \\
\hline KS-26 & Vegetable field without khejri plantation and 6 years of cluster bean crop during rainy season \\
\hline KS-27 & Vegetable field without khejri plantation and 6 years of cucurbits cultivation during rainy season \\
\hline
\end{tabular}




\begin{tabular}{|c|c|}
\hline KS-28 & $\begin{array}{l}\text { Vegetable field without khejri plantation and } 6 \text { years of cucurbits cultivation adopting drip } \\
\text { technology }\end{array}$ \\
\hline KS-29 & $\begin{array}{l}\text { Vegetable field with khejri plantation }(48 \mathrm{mx} 4 \mathrm{~m}) \text { and } 6 \text { years of cucurbit cultivation during rainy } \\
\text { season }\end{array}$ \\
\hline KS-30 & $\begin{array}{l}\text { Vegetable field with khejri plantation }(48 \mathrm{mx} 4 \mathrm{~m}) \text { and } 6 \text { years of cucurbits cultivation adopting } \\
\text { drip technology }\end{array}$ \\
\hline KS-31 & $\begin{array}{l}\text { Vegetable field with khejri plantation }(48 \mathrm{mx} 4 \mathrm{~m}) \text { and } 6 \text { years of cucurbits cultivation adopting } \\
\text { channel technology }\end{array}$ \\
\hline KS-32 & Field of khejri budded plantation of 6 years old $(16 \mathrm{mx} 4 \mathrm{~m})+$ Jharber as inter-crop $(4 \mathrm{mx} 4 \mathrm{~m})$. \\
\hline KS-33 & Field of khejri budded plantation of 6 years old $(16 \mathrm{mx} 4 \mathrm{mx} 4 \mathrm{~m})+$ Jharber as inter-crop $(4 \mathrm{mx} 4 \mathrm{~m})$. \\
\hline KS-34 & Field of khejri budded plantation of 6 years old $(24 \mathrm{mx} 4 \mathrm{~m})+$ Jharber as inter-crop $(4 \mathrm{mx} 4 \mathrm{~m})$. \\
\hline KS-35 & Field of khejri budded plantation of 6 years old $(24 \mathrm{mx} 4 \mathrm{mx} 4 \mathrm{~m})+$ Jharber as inter-crop $(4 \mathrm{mx} 4 \mathrm{~m})$. \\
\hline KS-36 & $\begin{array}{l}\text { Field of khejri budded plantation of } 9 \text { years old }(4 \mathrm{~m} \times 4 \mathrm{~m}) \text {, three seasons cluster bean crop and } \\
\text { normal culture for organic plot }\end{array}$ \\
\hline KS-37 & In and around periphery site of khejri - Thar Shobha budded plants of 9 years age old group \\
\hline KS-38 & In an around periphery site of seedling khejri plants of about 9 years old (control) \\
\hline KS-39 & $\begin{array}{l}\text { Field of khejri budded plantation of } 9 \text { years old }(48 \mathrm{mx} 4 \mathrm{mx} 4 \mathrm{~m})+9 \text { years of cluster bean crop } \\
\text { cultivation. }\end{array}$ \\
\hline KS-40 & $\begin{array}{l}\text { Field of khejri budded plantation of } 9 \text { years old }(48 \mathrm{mx} 4 \mathrm{~m})+9 \text { years of cluster bean crop } \\
\text { cultivation. }\end{array}$ \\
\hline KS-41 & Field without khejri rows +9 years of cluster bean cultivation \\
\hline KS-42 & Field without khejri rows +9 years of cucurbits cultivation adopting channel technology \\
\hline KS-43 & Field without khejri rows +9 years of cucurbits cultivation adopting channel technology \\
\hline KS-44 & Field of khejri budded plantation of 9 years old $(48 \mathrm{mx} 4 \mathrm{~m})+9$ years of cucurbits crop cultivation \\
\hline KS-45 & $\begin{array}{l}\text { Field of khejri budded plantation of } 9 \text { years old }(48 \mathrm{mx} 4 \mathrm{mx} 4 \mathrm{~m})+9 \text { years of cucurbits crop } \\
\text { cultivation }\end{array}$ \\
\hline KS-46 & $\begin{array}{l}\text { Field of khejri budded } 9 \text { years old }(48 \mathrm{mx} 4 \mathrm{~m})+9 \text { years of cucurbits cultivation adopting channel } \\
\text { technology }\end{array}$ \\
\hline KS-47 & $\begin{array}{l}\text { Field of khejri budded } 9 \text { years old }(48 \mathrm{mx} 4 \mathrm{~m})+9 \text { years of cucurbits cultivation adopting drip } \\
\text { technology }\end{array}$ \\
\hline
\end{tabular}

Table.2 Soil fertility status studies with khejri based crop production sites at CIAH, Bikaner

\begin{tabular}{|l|c|c|c|c|c|c|c|c|c|}
\hline \multirow{2}{*}{$\begin{array}{l}\text { Treatment } \\
\text { code }\end{array}$} & \multicolumn{10}{|c|}{ Soil sample parameters under investigation with 47 situation } \\
\cline { 2 - 11 } & $\mathrm{pH}$ & TDS & $\mathrm{EC}(\mathrm{ds} / \mathrm{m})$ & $\begin{array}{c}\text { OC } \\
(\%)\end{array}$ & $\mathrm{OM}$ & $\begin{array}{c}\mathrm{N} \\
\mathrm{kg} / \mathrm{ha}\end{array}$ & $\begin{array}{c}\mathrm{P} \\
\mathrm{kg} / \mathrm{ha}\end{array}$ & $\begin{array}{c}\mathrm{K} \\
\mathrm{kg} / \mathrm{ha}\end{array}$ & $\begin{array}{c}\mathrm{S} \\
\mathrm{kg} / \mathrm{ha}\end{array}$ \\
\hline KS-1 & 8.67 & 46 & 0.072 & 0.075 & 0.129 & 80.81 & 8.18 & 186.12 & 4.61 \\
\hline KS-2 & 8.71 & 55 & 0.086 & 0.086 & 0.148 & 92.66 & 8.90 & 185.28 & 5.44 \\
\hline KS-3 & 8.74 & 48 & 0.075 & 0.093 & 0.160 & 88.89 & 8.11 & 188.60 & 6.31 \\
\hline KS-4 & 8.80 & 67 & 0.105 & 0.088 & 0.151 & 94.28 & 8.16 & 193.20 & 7.50 \\
\hline KS-5 & 8.39 & 41 & 0.064 & 0.097 & 0.168 & 100.21 & 11.05 & 197.47 & 7.54 \\
\hline KS-6 & 8.53 & 84 & 0.131 & 0.092 & 0.159 & 99.67 & 29.10 & 106.81 & 7.01 \\
\hline KS-7 & 8.52 & 74 & 0.116 & 0.082 & 0.142 & 107.75 & 10.55 & 221.52 & 6.79 \\
\hline KS-8 & 8.71 & 120 & 0.188 & 0.094 & 0.162 & 101.02 & 10.20 & 220.68 & 7.18 \\
\hline KS-9 & 8.55 & 75 & 0.117 & 0.096 & 0.166 & 103.50 & 10.77 & 227.16 & 5.88 \\
\hline KS-10 & 8.49 & 77 & 0.120 & 0.084 & 0.144 & 90.24 & 9.55 & 226.68 & 6.97 \\
\hline
\end{tabular}




\begin{tabular}{|c|c|c|c|c|c|c|c|c|c|}
\hline KS-11 & 8.62 & 58 & 0.091 & 0.095 & 0.164 & 102.36 & 8.83 & 217.16 & 6.97 \\
\hline KS-12 & 8.37 & 41 & 0.064 & 0.099 & 0.170 & 104.76 & 11.15 & 227.52 & 7.62 \\
\hline KS-13 & 8.32 & 41 & 0.064 & 0.100 & 0.172 & 106.13 & 11.34 & 244.00 & 8.01 \\
\hline KS-14 & 8.80 & 42 & 0.066 & 0.090 & 0.155 & 96.98 & 8.26 & 216.30 & 6.53 \\
\hline KS-15 & 8.78 & 44 & 0.069 & 0.079 & 0.137 & 85.66 & 9.91 & 219.29 & 5.31 \\
\hline KS-16 & 8.79 & 43 & 0.067 & 0.067 & 0.116 & 72.73 & 10.12 & 215.63 & 5.92 \\
\hline KS-17 & 8.86 & 45 & 0.070 & 0.095 & 0.164 & 102.36 & 9.91 & 224.16 & 3.70 \\
\hline KS-18 & 8.81 & 46 & 0.072 & 0.091 & 0.157 & 98.38 & 10.48 & 203.58 & 5.05 \\
\hline KS-19 & 8.84 & 46 & 0.072 & 0.070 & 0.121 & 75.43 & 9.55 & 227.34 & 4.83 \\
\hline KS-20 & 8.92 & 47 & 0.073 & 0.083 & 0.142 & 88.89 & 10.77 & 220.05 & 4.52 \\
\hline KS-21 & 8.89 & 100 & 0.156 & 0.090 & 0.155 & 96.97 & 8.90 & 225.39 & 7.46 \\
\hline KS-22 & 8.85 & 90 & 0.091 & 0.073 & 0.125 & 78.12 & 9.55 & 226.63 & 6.09 \\
\hline KS-23 & 8.79 & 42 & 0.066 & 0.090 & 0.155 & 96.97 & 9.80 & 223.46 & 4.57 \\
\hline $\mathrm{KS}-24$ & 8.79 & 44 & 0.069 & 0.088 & 0.151 & 94.28 & 10.63 & 222.42 & 4.79 \\
\hline $\mathrm{KS}-25$ & 8.51 & 98 & 0.153 & 0.094 & 0.161 & 100.75 & 10.89 & 224.79 & 6.09 \\
\hline KS-26 & 8.40 & 111 & 0.173 & 0.093 & 0.159 & 99.67 & 8.93 & 212.83 & 5.22 \\
\hline KS-27 & 8.46 & 109 & 0.170 & 0.091 & 0.157 & 98.43 & 9.27 & 209.00 & 5.22 \\
\hline KS-28 & 8.52 & 102 & 0.159 & 0.084 & 0.144 & 90.24 & 9.56 & 212.23 & 6.31 \\
\hline KS-29 & 8.67 & 130 & 0.203 & 0.090 & 0.155 & 96.65 & 10.91 & 220.28 & 6.53 \\
\hline KS-30 & 8.44 & 93 & 0.145 & 0.090 & 0.156 & 97.51 & 9.72 & 224.38 & 4.35 \\
\hline KS-31 & 8.78 & 99 & 0.155 & 0.082 & 0.141 & 88.22 & 10.25 & 225.42 & 4.96 \\
\hline KS-32 & 8.78 & 43 & 0.067 & 0.075 & 0.129 & 80.81 & 8.84 & 215.78 & 3.48 \\
\hline KS-33 & 8.81 & 47 & 0.073 & 0.088 & 0.151 & 94.28 & 10.28 & 227.10 & 5.36 \\
\hline KS-34 & 8.81 & 45 & 0.070 & 0.067 & 0.116 & 72.73 & 10.70 & 225.34 & 6.09 \\
\hline KS-35 & 8.79 & 58 & 0.141 & 0.069 & 0.119 & 74.35 & 10.63 & 225.67 & 6.31 \\
\hline KS-36 & 8.73 & 54 & 0.084 & 0.090 & 0.155 & 96.97 & 10.15 & 223.00 & 6.54 \\
\hline KS-37 & 8.45 & 101 & 0.158 & 0.096 & 0.166 & 103.67 & 10.21 & 224.84 & 7.40 \\
\hline KS-38 & 8.44 & 95 & 0.148 & 0.085 & 0.147 & 91.59 & 8.64 & 214.79 & 7.40 \\
\hline KS-39 & 8.27 & 37 & 0.058 & 0.100 & 0.172 & 107.76 & 11.56 & 246.00 & 8.27 \\
\hline $\mathrm{KS}-40$ & 8.61 & 64 & 0.100 & 0.094 & 0.162 & 101.50 & 10.64 & 226.58 & 6.42 \\
\hline KS-41 & 8.59 & 58 & 0.091 & 0.173 & 0.297 & 185.87 & 13.15 & 184.50 & 6.31 \\
\hline KS-42 & 8.51 & 55 & 0.086 & 0.128 & 0.220 & 137.38 & 6.08 & 174.79 & 6.53 \\
\hline KS-43 & 8.73 & 70 & 0.109 & 0.087 & 0.151 & 94.28 & 9.34 & 181.84 & 7.18 \\
\hline KS-44 & 8.47 & 88 & 0.138 & 0.093 & 0.161 & 100.45 & 10.20 & 224.36 & 6.48 \\
\hline KS-45 & 8.53 & 67 & 0.105 & 0.096 & 0.166 & 103.69 & 10.87 & 218.95 & 7.01 \\
\hline KS-46 & 8.71 & 55 & 0.086 & 0.091 & 0.157 & 98.35 & 10.38 & 221.25 & 7.38 \\
\hline KS-47 & 8.57 & 70 & 0.109 & 0.092 & 0.158 & 98.91 & 9.76 & 216.87 & 6.61 \\
\hline Mean & 8.64 & 67 & 0.105 & 0.090 & 0.156 & 97.30 & 10.31 & 213.77 & 6.17 \\
\hline Minimum & 8.27 & 37 & 0.058 & 0.067 & 0.116 & 72.73 & 6.08 & 106.81 & 3.48 \\
\hline Maximum & 8.92 & 130 & 0.203 & 0.173 & 0.297 & 185.87 & 29.10 & 246.00 & 8.27 \\
\hline SD & 0.17 & 25 & 0.040 & 0.016 & 0.028 & 17.28 & 3.03 & 22.24 & 1.15 \\
\hline
\end{tabular}


With inspection of table 2 data, it is recorded that $\mathrm{pH}$ of treatment $\mathrm{KS}-13$ is $0.85 \%$ lesser than KS-5 of virgin sandy land. The organic carbon of this treatment enhanced prominently by $3 \%$ and there is noticeable change or increment in nutrients as nitrogen (5.57\%), phosphorus (2.56\%), potassium $(19.06 \%)$ and sulphur $(5.87 \%)$. When comparison is made with khejri model KM-9 as three years of establishment and cultivated land (KS-12), $\mathrm{pH}$ is $0.60 \%$ lesser in $\mathrm{KS}-13$ than KS-12. The organic carbon of KS-13 treatment is increased by one per cent than three years established orchard soil, and value of $\mathrm{N}, \mathrm{P}, \mathrm{K}$ and $\mathrm{S}$ content was increased by $1.29 \%, \quad 1.68 \%, \quad 6.75 \%$ and $4.87 \%$ respectively.

The data also highlight the treatment KS-12 i.e. khejri planting model - KM-9 as field of pair plantation $(24 \mathrm{mx} 4 \mathrm{mx} 4 \mathrm{~m})$ of 3 years age with three cluster bean inter-crop cultivation was found to be more fertile than other treatments of similar pattern. The soil $\mathrm{pH}$, TDS and EC of this situation were 8.37, 41 $\mathrm{ppm}$ and $0.064 \mathrm{ds} / \mathrm{m}$ and is $3.24,38.81$ and $39.18 \%$ lesser to mean values of soil samples under study, respectively. Good organic carbon content was recorded with KS-12 i.e. $0.0985 \%$ and is $12.57 \%$ higher than mean value from samples. The available N, P, K and $\mathrm{S}$ was good under KS-12 and is 104.76 , $11.15,227.52$ and $7.62 \mathrm{~kg} / \mathrm{ha}$, respectively and is $11.06,12.42,4.49$ and $24.1 \%$ higher than mean values of samples investigated. When we compared treatment KS-12 with best of virgin sandy field sample i.e. KS-5, it is observed that there was considerable change in $\mathrm{pH}$ of soil as $-0.24 \%$ and $\mathrm{OC}$ in soil increased by $2 \%$ whereas $\mathrm{N}, \mathrm{P}, \mathrm{K}$, and $\mathrm{S}$ content is enhanced by $4.34 \%, 0.90 \%$, $13.21 \%$ and $1.05 \%$ respectively.

The described data in table 2 revealed that field treatment KS-5 (virgin sand-dune land and as developed field with three years of cluster bean cultivation under rainfed situations) is found to be better than that of similar pattern of land-use under desert ecosystem. Soil sample $\mathrm{pH}$, TDS and EC of this production site was $8.39,41 \mathrm{ppm}$ and 0.064 $\mathrm{ds} / \mathrm{m}$, respectively and is $3.01,38.81$ and $39.18 \%$ lesser than the mean values from total samples under investigation. Organic carbon content of the experimental field site of KS-5 was $0.0972 \%$ and is $11.08 \%$ higher than mean of sampled field. The observations indicates that available $\mathrm{N}, \mathrm{P}, \mathrm{K}$, and $\mathrm{S}$ were much better in KS-5 than the similar pattern of land use, and amount of content was $100.21, \quad 11.05, \quad 197.47$ and $7.54 \mathrm{~kg} / \mathrm{ha}$ respectively. The respective nutrients were $6.24 \%$ higher, $11.41 \%$ higher, $9.31 \%$ lower and $22.80 \%$ higher from mean value of samples studied.

When we compared the production site situations study each other as treatments, there is something is remaining as impact of native grasses culture. With six year group of khejri budded plantations, inter-cropping of native grasses (sewan, dhaman and bhurhat) have their variable impact on soil properties and fertility build-up under rainfed crop culture, and three impressive and comparable combinations as treatments are KS-14 (khejri model-16mx4mx4m + three years bhurhat crop culture), KS-15 (khejri model$16 \mathrm{mx} 4 \mathrm{mx} 4 \mathrm{~m}+$ three years dhaman crop culture and KS-16 (khejri model$16 \mathrm{~m} \times 4 \mathrm{mx} 4 \mathrm{~m}+$ three years sewan crop culture). The data from table 2 revealed the $\mathrm{pH}$ value of these three treatments as KS-14 (8.80), KS-15 (8.78) and KS-16 (8.79) and was higher than $\mathrm{pH}$ value (8.71) of six year of khejri plantation plots, and are $1.02 \%, 0.80 \%$ and $0.91 \%$ higher than mean value of sole khejri plot. TDS of KS-14, KS-15 and KS-16 as treatment are considerably lesser $38.27 \%$, $35.33 \%$ and $36.80 \%$ than mean value 68.04 ppm of sites under study. Similarly, respective EC was also lesser $37.74 \%$, 
$34.91 \%$ and $36.79 \%$ than mean value $(0.106$ $\mathrm{ds} / \mathrm{m}$ ) with khejri plantation. The organic carbon of grass culture plots has great variations with value of $\mathrm{OC}$ content $(0.0843 \%)$ of khejri budded plantations and it is $7.14 \%$ higher from $\mathrm{KS}-14,5.69 \%$ lesser with KS-15 and $19.93 \%$ lesser with KS-16. The variation is also recorded in values of macro nutrients as nitrogen $(90.72 \mathrm{~kg} / \mathrm{ha})$, phosphorus $(9.97 \mathrm{~kg} / \mathrm{ha})$, potassium $(221.35$ $\mathrm{kg} / \mathrm{ha})$ and sulphur $(5.51 \mathrm{~kg} / \mathrm{ha})$ under sole khejri plantation. The content of nitrogen is increased $6.9 \%$ with KS-14 and decreased $5.58 \%$ and $19.83 \%$ with KS-15 and KS-16, respectively. Phosphorus content decreased by $17.15 \%$ and $0.60 \%$ with KS-14 and KS-15, and increased $1.50 \%$ under KS-16. Potassium level gets decreased in all the three grass treatments by $2.28 \%, 0.93 \%$ and $2.58 \%$ respectively. Sulphur has noticeable variations with these treatments as $18.81 \%$ higher with KS-14, 3.63\% lesser with KS-15 and $7.44 \%$ higher with KS-16.

\section{References}

Dwivedi, N.K., D.C. Bhandari and S.K. Verma (1997). Collecting Prosopis cineraria germplasm in western India. IPGRI Newsletter for Asia, the Pacific and Oceania, 22: 19.

Pareek, O.P. and A.K. Purohit (2002). Patch budding in khejri (Prosopis cineraria). Indian Journal of Horticulture, 59: 8994.

Samadia. D.K., A.K. Purohit and O.P. Pareek (2002). Genetic diversity in vegetable type khejri. Indian Journal of Agro- forestry, 4 (2): 132-134.

Purohit, A.K., D.K. Samadia and O.P. Pareek (2003). Studies on growth enhancement of khejri seedlings and in-situ budded plants. Annals of Arid Zone, 42 (1): 1-5.

Samadia, D.K. (2004). Horticultural Based Crop Production Site Management Approaches (HBCPSMA) - Innovative concept (unpublished). CIAH, Bikaner.

Pareek, O. P., A. K. Purohit and D. K. Samadia (2006). Graft compatibility among the Asian and Algaobia Prosopis species. Indian Journal of Arid Horticulture, 1 (2): 1-5.

Samadia, D.K., O.P. Pareek and A.K. Purohit (2006). Techniques for annual harvesting of sangri and loong - An approach to popularize khejri as a horticultural crop. Abstract of paper In: National Symposium on Livelihood Security and Diversified Farming Systems in Arid Region. January 14-16, 2005. Arid Zone Research Association of India, CAZRI, Jodhpur. 2.5: $30 \mathrm{p}$.

Samadia, D.K. (2014). Innovative concepts, techniques and practices for enhancing productivity of vegetable crops under hot arid agro-climate. Chapter in compendium of short course: Advances in water management and fertigation in fruit and vegetable crops of hot arid region in India (eds. Sharma, et al.,), CIAH: Bikaner. pp 47-53.

Samadia, D.K. (2015). Khejri-Thar Shobha: Grow for horticultural exploitation. Technical Folder, ICAR-CIAH: Bikaner, 6p.

\section{How to cite this article:}

Dinesh Kumar, D.K. Samadia, M.K. Jatav, S.R. Meena, B.D. Sharma and Singh, D. 2017. Scope of Improvement in Soil Fertility Build-up with Khejri Based Crop Production Systems under Hot Arid Agro-Climate. Int.J.Curr.Microbiol.App.Sci. 6(7): 1107-1115. doi: https://doi.org/10.20546/ijcmas.2017.607.134 